\title{
The Hyogo Framework for Action and its implications for disaster management and reduction in Africa
}

\author{
Dejo Olowu \\ Faculty of Law \\ North-West University, Mafikeng \\ djolowu1@yahoo.co.uk
}

\section{ABSTRACT}

At the World Conference on Disaster Reduction, Hyogo, Japan, in January 2005, the international community adopted a 10-year plan to make the world safer from disasters. The resultant Hyogo Framework for Action is the global blueprint for disaster risk reduction with the goal of substantially reducing disaster losses in human lives and socio-economic assets. What is the significance of the HFA for the adoption of disaster prevention, management and risk reduction frameworks in African States? Since 2005, what has been the attitude of African States to the promise of the HFA? In terms of policy and planning, how should African States engage the HFA towards securing human lives and properties against natural and human-induced disasters? With the myriad challenges of mass poverty and underdevelopment across Africa, what implications does the HFA hold for disaster risk reduction and management in African States? This article attempts to address this plethora of questions, drawing on lessons learned in Africa and beyond. The article examines the background of the HFA and its progress in shaping the global policy agenda towards disaster management and reduction. While the article acknowledges some of the inherent weaknesses in the promise of the HFA, it nonetheless accentuates its inimitable implications for broad legal and policy strategies towards ameliorating the usual horrific aftermath of disasters in Africa.

\section{KEYWORDS}

Hyogo Framework for Action; Africa; Nigeria; disaster risk reduction; preparedness; coordination.

\section{Introduction}

It is beyond polemics that from human-induced to natural, all over the world there have been series of disasters that have wrought devastation on lives and resources. Within the first decade of the 21st century alone, incidents of chemical spillages, explosions, earthquakes, landslides, thunderstorms, hurricanes, infernos, tornadoes, floods, wild fires, tsunamis, volcanic eruptions, dam collapses, violent uprisings and massacres have been reported with various degrees of destruction around the world. Institutional and individual observers of these incidents agree that there has been an increase in these occurrences over the past decade (Giuliani et al., 2009). ${ }^{\mathrm{I}}$ 
While the experiences of disasters vary from country to country, there are grim indicators that no State on the earth is insulated from disasters (ICSU, 2008:9).

For developing countries such as make up the African continent, the weakness of State infrastructures, absence of appropriate legal and policy frameworks and sometimes inadequate resources particularly render them more vulnerable to the gory consequences of large-scale disasters. The prevention, management and reduction of disasters are therefore a huge challenge for the majority of countries. It is remarkable to note that countries throughout the world have recognised the need to formulate a clear regulatory agenda aimed at the prevention, management and reduction of disasters. A manifestation of this was the Hyogo Framework for Action 20052015: Building the Resilience of Nations and Communities to Disasters (HFA), ${ }^{\mathrm{II}}$ a global strategy to reduce disaster risks.

Although significant progress has been made in recent years in global disaster scholarship, especially in the field of modelling spatial impacts of disasters in regional contexts, these advancements in empirical, analysis-oriented and strategy-focused approaches have dealt minimally with the African dimension. Scholarly works on disasters in Africa could thus at best be described as incipient. This may be due to the fact that disasters are perceived as being quite different from other economic or development-related events, in terms of their frequency, scope, and predictability. It may therefore be the case that there might not be sufficient observations to construct a unique theoretical framework for disasters as a phenomenon in the broader development discourses in Africa. This article conceives of disasters as having direct or indirect implications for African economies and development phenomena, such as drastic changes in public policy and/or regulation which are often required in the chaotic aftermath of major disasters. This is the background against which this article should be received. It represents a modest attempt at stimulating interest in an otherwise marginalised and obscure field, more particularly in the weak and developing States of Africa.

Using Nigeria as its nucleus of study, this article exposes some of the underpinning dynamics which make an integration of the HFA a sine qua non for effective disaster management and reduction in Africa. The choice of Nigeria for this purpose is neither abstract nor arbitrary: over the past decade, this particular State has experienced a combination of several human-induced and natural disasters which far outweigh the frequency and magnitude of similar occurrences elsewhere in Africa (Bawa \& Meierhans, 2006). Nigeria's disaster profile is formidable - the broad assortment of hazards in Nigeria currently includes frequent oil spills and pipeline explosions; a rise in the number and severity of floods, especially in Jigawa, Kano, Gombe and southern states like Lagos due to climatic change and urbanisation (IFRC, 2008; Adeaga, 2009); the threat of desertification due to uncontrolled use of wood for fuel, pest infestations as with quella birds and locusts in the Yobe-Borno axis; an outbreak of the dreaded avian influenza $\mathrm{H} 5 \mathrm{~N} 1$ (bird flu) in some parts of the country; droughts and land use degradation; gully erosion in the south-eastern states of the country; wind storms in northern parts of the country; horrific plane crashes and vehicular accidents; fire disasters across the country especially market infernos in many parts of the country; marine and coastal erosion in the coastal areas (Egberongbe et al., 2006); ammunition dump explosions; collapsed buildings; 
communal clashes; and violent religious uprisings (Agbo, 2007). Some of these incidents are as recent as January 2010.

Recognising that resource constraint has always been the mantra of African States towards welfare-oriented policies and programmes such as covered by the theme of this article, an attempt is made at identifying other factors impeding the emergence of effective disaster management and reduction in Africa beyond the issue of resources. Although generally extrapolating from its direct linkage with Africa's most populous country, Nigeria, this article nevertheless accentuates the trajectory of the implications of its overarching discussions for other African States.

\section{International Initiatives on Disaster Management and Reduction}

Towards the end of the 20th century, ubiquitous occurrences of disasters had aroused mutual consciousness in numerous States of the need to tackle the challenges of disaster prevention, management and reduction. Towards this end, the United Nations General Assembly had declared the decade beginning 1 January 1990 as the International Decade for Natural Disaster Reduction (IDNDR). III This was the culmination of a series of diplomatic and high-level meetings on the subject beginning with the establishment of the mandate of the Office of the UN Disaster Relief Coordinator, as set out in its Resolution 2816 (XXVI) of 14 December 1971. IV Since the adoption of the IDNDR, there have been several initiatives at the global level aimed at managing and reducing the impact of disasters on development. One such key effort is the United Nations (UN) International Strategy for Disaster Reduction (ISDR) which promotes sustained global advocacy and regional cooperation in disaster risk reduction. The ISDR focuses on consolidating global efforts and promoting collaboration in reducing risk and vulnerability to all forms of disasters (Konoorayar, 2007:373-375; Beer, 2007:469). V

Of particular significance for this discussion was the World Conference on Disaster Reduction held in Kobe, Hyogo, Japan, from 18 to 22 January 2005. The outcome of the negotiations at this global summit constitutes the overarching thrust of this article.

\section{Hyogo Framework for Action: Overview and Promise}

The 2005 World Conference on Disaster Reduction held in Hyogo, Japan, was organised to assess the progress made on disaster risk management and reduction after the Yokohama Conference of $1994,{ }^{\mathrm{VI}}$ and to set thematic agendas for the next decade. The main outcome of the conference, the Hyogo Declaration and the corresponding HFA, adopted in January 2005 by 168 governments, represents a strong commitment from the international community to address disaster reduction and to engage in a determined, results-based plan of action. The HFA also represents a global blueprint for disaster risk reduction efforts within a ten-year plan.

At the heart of the HFA is the concept of Disaster Risk Reduction (DRR). DRR is a conceptual framework intended to systematically avoid (prevent) and limit (prepare for/mitigate) disaster risks with regard to losses in lives and the social, economic and environmental assets of communities and countries. DRR contemplates that effective strategies aimed at minimising the consequences of disasters must be instigated well before a disaster strikes; in other words, it 
is crucial to shift the focus away from merely responding to disasters, and to focus particularly on disaster prevention and preparedness activities (Chagutah, 2009). In this respect, Momoh and Akinyede (2008) have suggested that the preparedness aspect is the most potent challenge for African States in the management and reduction of disasters. "Preparedness" here involves not only developing plans to respond to a disaster as it threatens to occur but also an estimation of emergency requirements and their mobilisation in time to meet the emergency needs. The most vulnerable areas can be identified and contingency plans drawn up with necessary stockpiles and supplies of materials. Prediction, warning, and coordination thus constitute prerequisites for disaster preparedness (Saechao, 2007:683-684). The HFA sought to tackle this challenge headlong, doing away with the traditional dichotomy between natural and human induced disasters. From the World Conference on Disaster Reduction and especially the agreed expected outcome and strategic goals, five priorities for action are stated as part of the HFA, together with some illustrative and research-specific sub-items, namely (1) to ensure that disaster risk reduction is a national and a local priority with a strong institutional basis for implementation; (2) to identify, assess and monitor disaster risks and enhance early warning; (3) to use knowledge, innovation and education to build a culture of safety and resilience at all levels; (4) to reduce the underlying risk factors; and (5) to strengthen disaster preparedness for effective response at all levels.

Although the text of the HFA contains no specific time-bound targets, it does include a commitment to the means for setting them up. To this end, the mechanisms established by the HFA include the Global Platform which is the main forum for continued and concerted emphasis on disaster reduction, providing strategic guidance and coherence for implementing the HFA, and for sharing experiences and expertise among all its stakeholders; the National Platforms which are officially declared national coordinating multi-sectoral and interdisciplinary mechanisms for advocacy, coordination, analysis and advice on DRR, as well as HFA Progress Reports which assess national strategic priorities in the implementation of DRR actions and establish baselines on levels of progress achieved in implementing the HFA's five priorities for action.

Under the HFA, States have pledged to "publish national baseline assessments of the status of disaster risk reduction", to "publish and periodically update a summary of national programmes for disaster risk reduction"; and to "promote the integration of risk reduction associated with existing climate variability and future climate change." Whereas the traditional approach to disaster issues had been "Compensatory Disaster Management", which emphasises postdisaster activities such as relief and rehabilitation, the HFA introduced a new emphasis on "Prospective Disaster Management" which lays importance on prevention and mitigation (Konoorayar, 2006:361).

It will be recalled that prior to the HFA, a consensus was emerging among disaster watchers that concentrations of people and activities on safe sites were not a source of vulnerability but that the unequal distribution of resources, the marginalisation of segments of the population and informal activities, and their exclusion from planned and serviced areas, are what compel people to occupy unsafe sites resulting in their vulnerability (Harris, 1983; Anderson, 1985; 
Skeldon, 1990). There is a necessity, therefore, to look at the changes in urban systems which create such characteristics in establishing the correlation with vulnerability.

The global event in Kobe was thus unique in many other ways: the international community unanimously recognised disasters essentially as an expression of development failure, and their reduction as a matter of good governance, risk reduction and livelihood focus. The HFA amplified the insights and ideas of civil society organisations and the International Committee of the Red Cross (ICRC), giving these a global appeal, establishing a global mandate for disaster risk reduction, and arranging them into attainable actions (Walker, 2005).

Like most other initiatives involving diplomacy and high-level negotiations, however, the HFA is not without its flaws. The HFA is a top-down process, UN and donor-driven, and flows through formal institutional mechanisms and arrangements. National platforms are being set up and thematic platforms are being formed at the instance of those who work at the global level, in the UN or donor agencies. Although large numbers of individuals and organisations are involved, and are being consulted and engaged with good effect, the process is still decided at the top, not according to local agendas (Bhatt, 2007). In the years after the advent of the HFA, the prevalent reasoning has been that the ordinary people at the grassroots level are strategically better placed to address disaster challenges and set reduction priorities (Benson et al., 2001; Dekens, 2007; Gaillard \& Cadag, 2009; Pelling \& Wisner, 2008). This line of reasoning informs the thrust of this article.

\section{African Responses to the Hyogo Framework for Action}

Like many other parts of the world, Africa has had its share of disasters of varying degrees. Yet, history demonstrates that most occurrences of natural or human-induced disasters is poorly managed, resulting in enormous losses of lives and properties. Momoh and Akinyede (2008:61) have contended that the inability of many African countries to effectively manage and reduce disasters is traceable to inappropriate planning and inadequate funding, reliance on outdated or dysfunctional systems of disaster management, lack of proficiency, inability to access technological data, indifference and so on. For instance, the transition of digital maps may be complete at provincial or national level, yet many African countries still rely on and use printed maps. In many African countries, the process of digitising the bulk of hazard and regulatory maps is still ongoing, while recent maps and related information, if they exist, are stored in GIS. The access to this system is far from being shared among administrations or even among border states or countries.

The management of natural disasters is often beyond the scope of ground-based capabilities and investing in space technologies for disaster relief and mitigation is therefore well justified on the basis of the data obtainable from them. Unfortunately, such satellite data have not been readily adopted by mapping agencies and emergency response personnel on the continent for quick detection of emergency change information for planning, monitoring and damage assessment. Some administrations do not know or may not even have access to relevant global organisations and their functions in disaster management (Momoh \& Akinyede, 2008). This 
being so, when a disaster occurs, many African countries are caught unawares and await the intervention of the Western States while they remain as top news in the world media.

The HFA pointedly acknowledges the particular vulnerability of African States. The international community had expressed its concern about disasters in Africa in the following words:

Disasters in Africa pose a major obstacle to the African continent's efforts to achieve sustainable, development, especially in view of the region's insufficient capacities to predict, monitor, deal with and mitigate disasters. Reducing the vulnerability of the African people to hazards is a necessary element of poverty reduction strategies, including efforts to protect past development gains. Financial and technical assistance is needed to strengthen the capacities of African countries, including observation and early warning systems, assessments, prevention, preparedness, response and recovery. ${ }^{\mathrm{VII}}$

Towards the global goals of disaster management and reduction, States of the African region have taken several steps, at least at the formal level, including conducting a baseline study of disaster reduction potential in Africa in 2004; preparation of a preliminary African Regional Strategy Document by the African Union (AU), with the support of UN/ISDR Africa, African Development Bank, in 2004; the hosting of an African Ministerial Conference to advise UN/ ISDR Africa and other institutions on DRR issues, in 2006; the organisation of an African Ministerial Conference on DRR in Addis Ababa to pursue the HFA (HFA) agenda, in December 2005; the establishment of an African Advisory Group on DRR to advise UN/ ISDR Africa and relevant regional institutions, 2005; the adoption of the African Strategy Document on DRR by the African Ministerial Conference on Environment (AMCEN), in Brazzaville, in May 2006; the commencement of the projectisation of the African Regional Plan for DRR by the AU after May 2006 (Agbo, 2007); and more recently, the hosting of the Second Africa Regional Platform for DRR in Nairobi, Kenya, in May 2009 (AU, 2009).

Regrettably, as with many other people-oriented initiatives, most African States have hardly moved beyond the scope of formal commitment to declarations and high-level meetings: compliance with the agreed terms of initiatives has always been problematic. As of 25 February 2009, only 22 African States had established National Platforms as envisaged by the HFA. These were: Botswana; Burkina Faso; Burundi; Cape Verde; Comoros; Congo; Djibouti; Gabon; Ghana; Kenya; Lesotho; Madagascar; Mali; Niger; Nigeria; Senegal; Seychelles; South Africa; Tanzania; Togo; Uganda; and Zambia. ${ }^{\text {VIII }}$ Furthermore, in the most recent reporting period under the HFA (2007-2009), only 18 African States submitted National Progress Reports as agreed under the HFA. ${ }^{\text {IX }}$

In recent times, however, many African countries have risen to the task of disaster management and reduction not only for their respective countries but for the continent at large. Ostensibly because of the country-wide locust invasions of the 1980s, 1990s, and 2003; the influx of refugees in its Western Region and bush fires in the Lower River Region, the Serrekunda 
market fire disasters, the Kanifing East Estate fire incident in 2006, the Ebo Town floods in 2002, 2005 and 2007 causing loss of lives, of huge properties and contributing to food insecurity and occasioning other negative consequences for economic development in the country, the tiny West African country of Gambia has been compelled to adopt several normative and policy frameworks along the lines of the HFA. These include the Gambia Vision 2020 Document; the National Environment Management Act (NEMA) in 1994; the first and second GEAP and desertification conventions; the National Disaster Emergency Relief and Resettlement Committee; the Capacity Building for Sustainable Development (CAP 2015) Project, the MDG Reports 2003, 2004; and the Poverty Reduction Strategy Paper (PRSP) (The Gambia, 2008). By the same token, South Africa has adopted a comprehensive manual of disaster management guidelines for all of its three tiers of government, focusing on stages of preparedness based on peculiar vulnerabilities (SANDMC, 2003; Van Riet, 2008; Chagutah, 2009).

Nigeria, South Africa and Egypt have also acquired the relevant facilities and established COSPAS SARSAT (Search and Rescue Satellite) local user and mission control centres. COSPAS SARSAT is a satellite system designed to provide distress alert and location data to improve disaster response by facilitating the location of crashed aircraft and ships in distress in collaboration with relevant response and Search and Rescue organisations. The implications of the COSPAS SARSAT programme for disaster management, especially related to aviation and marine transport operations, cannot be over-emphasised, particularly with reference to disaster locations to ensure prompt rescue management. These countries now have the means to receive and be the hub for distributing alert distress data in the West, South and North African subregions. The tasks before the institutions vary from search and rescue operations connected with aviation and marine transportation-related disasters to earth-observation data services such as the use of remote sensing and meteorological satellites data, and other services related to disaster management (Momoh \& Akinyede, 2008). In Nigeria, for example, such institutions include national and states' Emergency Management Agencies, the National Space Research and Development Agency (NASRDA), the Nigerian Meteorological Agency, federal and state Ministries of Environment and the National Institute for Oceanography.

Despite the few identified efforts, severe challenges of compliance remain. The Global Facility for Disaster Reduction and Recovery (GFDRR), a partnership of countries and international organisations that are committed to helping developing countries reduce their vulnerability to natural hazards and adapt to climate change, recently reported that disaster risk reduction is now an integral part of national development strategies in only 15 African countries: Burundi, Cape Verde, Central African Republic, Congo Republic, Djibouti, Gambia, Liberia, Madagascar, Malawi, Mozambique, Niger, Rwanda, Sao-Tome and Principe, Sierra-Leone, and Togo (GFDRR, 2009:7). It is instructive to note that Nigeria is not among these countries. In its 2009 Reports, the GFDRR reported that apart from integrating DRR into sector development policies as well as planning and programs for sustainable development, governments in Ethiopia, Ghana, Madagascar, Morocco and Mozambique, among others, are implementing risk-reducing sector development policies particularly in urban development, 
water management, community-driven development, natural resource management, and infrastructure, and that these governments have strengthened social safety nets for building resilience to cope with disasters and anticipated climate impacts (GFDRR, 2009:8-9).

\section{Frameworks for Disaster Risk Management and Reduction in Nigeria}

The constant reportage of disasters occurring in Nigeria in the print and electronic media signals the enormous vulnerability of Nigerians to day-to-day natural and human-induced hazards. Recent Nigerian history is replete with various accidents and mishaps which reveal the stark lack of preparedness of this populous State to deal with emergencies. Multiple deadly car accidents have occurred, not only because of poorly-maintained roads and unroadworthy vehicles, but also because emergency medical and rescue services are unable to arrive swiftly at the scenes of the accidents. Nigeria's inadequate disaster management systems were even more harshly exposed when the nation endured a series of air crashes between 2005 and 2006. All the violent conflicts and civil disturbances which ubiquitously flared up in many parts of the country over the past decade were characterised by the slow response of the security, emergency and relief agencies to crisis spots, and the consequent needless prolongation of the suffering of those who had been affected by them. As Nigeria marked the eighth anniversary of the 2002 Ikeja ammunition depot explosion disaster this year, and as the world continues the mop up activities following the recent massive earthquake devastation of Haiti, it has become imperative for Africa's most populous State to radically reorganise its disaster response capability, and to prepare a specific plan to improve the response capacities of the local people, improve their livelihood in everyday life, for example, by strengthening and improving housing quality, gainful employment and access to income. The urgency of these tasks has been made even more compelling by the fact that the country is reportedly within an earthquake-prone zone (Muanya, 2010).

That Nigeria lacks the most basic standards of disaster risk prevention, management and reduction is a subject that has received considerable attention (Adedoyin, 2004; Ehiawaguan, 2007). ${ }^{\mathrm{X}}$ By international standards, oil pipes ought to be replaced after 15 to 20 years, but most pipelines in use in Nigeria are about 20 to 25 years old, making them vulnerable to corrosion and leakage. In some cases, the pipes are laid above ground level without adequate surveillance, exposing them to wear and tear and other dangers (Egberongbe et al., 2006; Omonisini et al., 2010). Egberongbe et al. (2006) and Omonisini et al. (2010) also noted that most of the facilities were constructed between the 1960s and early 1980s to the then prevailing standards. The oil pipeline on the coast of Lagos that was buried when it was first laid is now exposed to the surface by the process of erosion. Despite all the grandstanding and posturing by state officials, Nigeria lacks a system of healthcare which would enable medical care to be effectively dispensed in the event of a disaster (Garba et al., 2000; Sanni, 2005); its building codes are inadequately enforced and consequently unable to significantly halt the collapse of buildings (Ehiawaguan, 2007); fire and other safety drills are neither widely practised nor as well-known as they should be (Adedoyin, 2004); in the 2002 Ikeja ammunition depot explosions, for example, the greatest loss of life came from the panic-stricken hundreds of residents who rushed to their deaths in the Oke-Afa canal in Lagos, in their efforts to escape the accidental bombings 
(UNDAC, 2002; Ehiawaguan, 2007; Agbo, 2007); and national emergency relief agencies often watch helplessly as various disasters and upheavals increase the numbers of internally displaced persons (IDMC, 2009).

Nigeria's patent inability to meet the requirements of everyday emergencies becomes even more worrisome in the light of a recent report by scientists from the National Space Research and Development Agency (NARSDA) that the country is very likely to experience an earthquake between now and 2028. According to recent scientific findings, tremors previously experienced in Abeokuta; Ijebu-Ode; Warri; Lagos; Umuahia; Bauchi; Yola; Kano; and Gombe, are an indication of much larger tremors to come (Muanya, 2010). As seen in previous incidents including the Haitian episode, an earthquake is the most wide-ranging of disasters. Apart from the mass collapse of buildings, the destruction of roads, airports and seaports makes it particularly difficult for emergency rescue services to respond effectively. The sheer size of the disasters wrought by earthquakes is such that even the most efficient systems can be overwhelmed, just as Hurricane Katrina and similar massive disasters showed (Hultman, 2006; Kent, 2006:198-205; De Urioste, 2006:194). The most recent example of an earthquake's destructiveness has been seen in Haiti, and it should provide Nigeria with sobering food for thought.

Is it the case that Nigeria has no laws or structures on the subject of disasters? By no means. Even though legislation on disaster management in Nigeria is still an incipient phenomenon, there is a broad legislative framework known as the National Emergency Management Agency (NEMA) Act which established the NEMA with a comprehensive mandate to manage disaster in all its ramifications. ${ }^{\mathrm{XI}}$ Since NEMA does not have a full complement of fire-fighters, security personnel, road marshals amongst other outfits required to tackle all disasters like fire, floods, landslides, epidemics, and violent clashes, the central responsibility of NEMA is to mobilise and coordinate respective agencies such as the Nigerian Fire Services, the Nigeria Police, the Nigeria Security and Civil Defence Corps, the Federal Road Safety Commission, the Federal Ministry of Health and even the non-governmental organisations like the Red Cross. It has been recognised that one of the biggest problems disaster responders face in providing relief is confusion and lack of coordination (Anderson, 1997; Hultman, 2006). Lack of coordination hampers relief efforts in areas affected by disasters and this is where the mammoth challenge of disaster preparedness lies in Nigeria despite all official planning and programming. The NEMA Director-General, Air Vice-Marshal Audu-Bida, did not mince his words when he described the prevalent Nigerian situation this way: "When there's a fire incident of course, we expect the fire fighters to be there... We just coordinate their things. We don't have the specialised personnel to handle some of these mishaps. The whole of NEMA staff is less than 300. We must partner with our stakeholders for them to respond to disasters promptly. The only way to achieve this is to come together and partner and work towards realising a common objective."XII

For one, fire can be a natural and beneficial disturbance of vegetation structure and composition, and help in nutrient recycling and distribution. However, substantial uncontrolled burning does occur across Nigeria, caused by a variety of factors including arson; improper channelling of electricity; forest burning for hunting purposes; pipeline explosions or oil bunkering, with 
destructive consequences. Effective actions to limit these are necessary to protect life and property, as well as to reduce the current burden of emissions on the atmosphere and subsequent adverse effects on the global climate system. A major handicap to fire management in Nigeria is the lack of accurate fire records, detailing the extent of the problem. Coupled with this is the lack of basic fire fighting skills among the generality of the ordinary people, beyond the traditional notion of quenching fire with water. Even at that, the resources for fighting massive infernos are lacking in local communities. The Summary of Global Vegetation Fire Inventory, for example, contains no data at all for a majority of African countries, including Nigeria (Adedoyin \& Olanrewaju, 2006). ${ }^{\text {XIII }}$

Disasters, whether natural or human-induced, are an inevitable fact of life. They may not be avoidable, but preparedness can go a long way in the limitation of their consequences. Nigeria needs to overhaul institutions like the NEMA, the fire services, and the police, whose responsibility it is to deal with emergencies. Disaster management and reduction should not be limited to these agencies alone; fire drills and related procedures should be integrated into the curricula of primary, secondary and tertiary institutions. Communication facilities should be re-tooled to accommodate emergency frequencies and channels, so that the citizenry can be reliably informed of exactly what to do whenever any kind of emergency arises, and are equally equipped with the basic resources to tackle such emergencies. Adequate preparation is the only true response to disaster. The country must learn to work more closely with voluntary agencies like the Nigerian Red Cross.

Nigeria has the largest population on the African continent. Despite its rich diversity of economic potentials and influence in West African and the continent, it has been plagued by political, ethno-religious, communal and social conflicts that have escalated in scale and dimension since the return of democracy in 1999. An effective DRR system for Nigeria must be about stronger building codes, sound land-use planning, better early-warning systems, environmental management and evacuations plans and, above all, education. Damage can be reduced if only people are made aware of the risks and are equally equipped with the basic resources to tackle such emergencies. Humanitarian and non-governmental organisations should work with communities to draw maps of villages, identify houses and areas most at risk so that they can protect them; increase local community capacity to address the most urgent situations of vulnerability; and involve vulnerable communities in contingency planning meetings, annual lessons learnt conferences and risk appraisal meetings. Of course, this line of action will have to be stimulated by concrete policy planning and budgetary processes from State institutions. This is where the HFA makes its entry into the challenges and weaknesses identified thus far in this article.

\section{Implications of the HFA for Disaster Risk Management and Reduction in Africa}

Traditionally, disasters have been conceived of as unpredictable and unpreventable events. However, the human role is now recognised in contributing to disasters through such acts as the construction of housing on unstable lands; the depletion of forests that cause downstream flooding; or land-degradation that causes reduced agricultural productivity; or inter-group 
conflict that leads to food shortages, to name only a few (Agbo, 2007; ICSU, 2008; Adeaga, 2009). Acknowledging that human actions play a significant role is a first step toward assuming responsibility for mitigating the consequences of, and preventing, future disasters. Ongoing grassroots development is another effective 'disaster response' (i.e. preparedness, prevention, mitigation) strategy. It is thus critical that the essential linkage between disaster proneness, the provision of assistance through disaster response programs and long-term development be recognised as first steps in the necessary new conceptualisation for addressing disasters.

The first and most basic responsibility of all States under the HFA is the formulation of a national framework on DRR. As of today, Nigeria has yet to finalise its national disaster management framework (Mukhtar, 2009). If Nigeria, and indeed all other defaulting African States, could practically embrace the HFA, most of the tenets of the HFA would assume practical application and integration in the management and reduction of disasters on the continent. Well-managed institutions may assist the countries in springing back quickly after disasters occur. Often, the weakness of civil society institutions and the lack of good governance, evidenced by corruption, the selection of high level managers on political rather than professional criteria, incompetence leading to inappropriate responses, the neglect of preparedness, and an underestimation of severity often compensated for by an overreaction, ensures that the impact is greater and lasts longer. In the same vein, disasters that were not properly managed have contributed significantly to the loss of skilled personnel, diversion of scarce resources, and destruction of infrastructure, a negative investment climate and political destabilisation.

To be effective, therefore, approaches to managing disasters should cover all aspects of disaster management as envisaged by the HFA and also include such aspects as prevention, mitigation, preparedness, response, recovery and disaster-related development. Some of the activities that are required for effective preparation are: vulnerability assessment, planning, information systems, institutional framework of development, warning systems, public education and training, and the development of a short-term and longer-term mitigation strategy. These activities should be an integral part of 'normal' local government activities that are expanded when needed; vulnerability assessment, for example, is a long, involved process that cannot be conducted only when an isolated disaster occurs.

An important aspect of long-term disaster preparedness is that such plans should not run counter to, or hinder, development. In some previous disasters, for example, it has been shown that the negative impacts, particularly on the poor, have been the result of the physical causes of the event as well as a result of poor or inadequate development (Goyet \& Griekspoor, 2007). Poverty often exacerbates vulnerability to disasters, and disasters in turn contribute to the continuation of the cycle of poverty. Drawing on experiences from various developing countries around the world, Alcantara-Ayala (2002:108) asserted that the occurrence of natural disasters in these countries is compounded by two main factors, namely their geographical location and geological-geomorphological settings as well as their historical development problems, which increase their high vulnerability to natural disasters. Analysing the patterns of industrial and residential development that have emerged extensively around major cities such as Buenos 
Aires, Mexico City, Sao Paulo, Seoul and Kuala Lumpur, several authors have demonstrated that while natural hazards cannot be prevented, the understanding of the process and scientific methodologies to predict patterns of behaviour in such processes can be powerful tools to help reduce natural vulnerability (Alcantara-Ayala, 2002:119; Srinivas \& Nakagawa, 2008:6; Cuaresma \& Obersteiner, 2008:214; Pelling \& Wisner, 2008:8). Disaster management initiatives and plans should therefore not run counter to development and should, where possible, complement those programmes that already exist in an area.

There are also two ways in which the disaster-response community should alter its operations in order to address the disaster management dilemma. First, providers of disaster assistance must develop systems for incorporating the human, social and political aspects of their work rather than operating as if disaster responses are wholly managerial and logistical endeavours. The people and agencies involved in disaster response need to develop new decentralised and participatory management approaches that facilitate timely, efficient and accurate identification of real relief needs and efficient and equitable delivery of assistance. These approaches must involve victims, relying on their knowledge and competencies to set priorities and to make allocation decisions and arrangements. If such new approaches are developed, it is very likely that both the efficiency and equity of disaster assistance will be improved in the short run. Even if, in some cases, involvement of victims in planning and implementing disaster responses delays a response, as shown in studies on South Africa generally (Van Niekerk, 2006), the landslide disaster in Cameroon (Zogning et al., 2007), and in Ethiopia and the Rift regions (Abebe et al., 2010), the results in the long run in terms of the reduced likelihood of long-term dependency-creation will be significant. Second, systems of accountability should be developed that can be used to assess and monitor the longer-term impacts of disaster response programs. To date, systems of accountability emphasise the importance of tracking relief goods to ensure that they reach the appropriate target groups while financial accounting concerns primarily the donor communities. Alternative systems that incorporate the perspectives of recipients, particularly those that monitor such things as tendencies toward increasing dependency or disruption of markets in ways that will have lasting negative incentive effects, must become as important in evaluating the effectiveness of relief as those that are focused on logistical efficiency (Ingram et al., 2006; Pelling \& Wisner, 2008:47).

All in all, coordination with other humanitarian actors and volunteers is necessary to improve the overall response in disaster situations and to avoid duplication and overlap of effort. This is one other area that requires dire attention by Nigeria's NEMA and its counterparts across the African continent.

Furthermore, in consonance with the HFA, African countries should not only integrate and take up space-based technology as a spin-off of international initiatives, but enhance its capability in disaster management by co-opting the available technological resources of many of the countries on the continent whilst building capacity and establishing institutional cooperation. Any venture or statute to sustain national initiatives to meet challenges for disaster management and reduction must be encouraged in order to reduce risk and vulnerability of the population to natural and human-induced disasters. 
In sum, the core gaps and challenges which require attention and more specific interventions at country level in Africa for compliance with the HFA are as follows:

(a) adoption of risk reduction strategies and national action plans that create a consensus amongst all key stakeholders on an all-of-government risk reduction agenda covering national and local levels (HFA priority area 1);

(b) gradually strengthening multi-hazard and risk monitoring capabilities while emphasising the creation of integrated, user-friendly information management systems that can inform the design and regular review of national and local risk reduction strategies and initiatives (HFA Priority Area 2);

(c) creation of all-inclusive risk reduction programs in the educational sector through primary, secondary and higher education; and addressing informal education needs, as well as interventions to increase structural resilience of educational buildings (HFA priority Area 3);

(d) promotion of systematic integration of DRR and Climate Change Adaptation in weaker/ high risk countries like Nigeria (HFA priority Area 4);

(e) design of programs and initiatives to address underlying risk while prioritising sector(s) and areas that are at high risk and/or demonstrate particular interest in risk reduction and cooperation (HFA priority Area 4);

(f) ensuring that communities and civil society are at the heart of all aspects of preparedness, response and recovery strategies and planning (HFA priority Area 5); and

(g) developing more specific benchmarks and indicators of progress at national levels against national targets and strengthening national and sub-regional monitoring and reporting capacity.

Flowing from the above, it is submitted that the HFA is feasible and dynamic; it can be applied to local African needs and peculiarities if suitable processes are developed and resources human and financial - are allocated to civil society organisations to claim its ownership. Its sustainability lies more in resourcing its applications and innovations, rather than achieving state-planned outputs and outcomes in a projectised way as currently being done. Ultimately, the HFA must remain in the joint custody of State and society.

\section{Concluding Remarks}

Subsequent to the 2004 Indian Ocean tsunami, the international community recognised the lack of disaster preparedness from not having a proper warning system in place, which resulted in the failure to mitigate harm to the people in disaster-stricken regions. In 2005, the United Nations World Conference on Disaster Reduction was held in Kobe, Hyogo, Japan. As a result of this conference, the HFA 2005 - 2015 was adopted. The HFA acknowledged the urgent need to build the capacity of disaster-prone countries and particularly developing states in limiting the impact of disasters by increasing bilateral, regional and international cooperation. The HFA also sets out a unified, multi-hazard approach to disaster risk management for 
disaster prone countries such as those found in developing states. Although the HFA calls for an all-inclusive perspective to be integrated into all disaster risk management plans, policies and decision-making processes, in most countries, the State's response to disasters has been short-sighted and poorly coordinated. Although the lack of technical expertise and human and material resources would always be plausible excuses for weak responses, such efforts are typically characterised by corruption and poor planning, despite the huge amounts spent on disaster management agencies.

While African States are part of the global initiative towards disaster risk reduction and management, their overall compliance and performance have been problematic. This article has highlighted some of the peculiar shortfalls in the compliance of African States with the HFA agenda, accentuating the need for continent-wide embrace of its tenets.

Contending that lack of preparedness and coordination are the two most problematic issues for African States in terms of disaster management and reduction, this article has advocated a renewed commitment for the sake of the most vulnerable populations. A strong case is made that active civil society participation, particularly of the ordinary people, skilled professionals, humanitarian relief agencies and of course victims, who can identify differentiated needs, priorities, skills and capacities before and after disasters, must no longer be ignored.

Far from being an ex cathedra pronouncement on all the dynamics that should inform the emergence of an effective regime of disaster risk management and reduction in Africa, this article will have served its purpose if it stimulates further intellectual discourse.

\section{References}

ABEBE, B., DRAMIS, F., FUBELLI, G., UMER M. \& ASRAT, A. 2009. Landslides in the Ethiopian highlands and the rift margins. Journal of African Earth Sciences, 56(4-5):131-138, Mar.

ADEAGA, O. 2009. Planning and warning tools for flood disaster management in Lagos Mega City' Fifth urban research symposium 2009. [Web:] http://www.urs2009.net/docs/papers/Adeaga.pdf [Date of access: 25 Feb. 2010].

ADEDOYIN, B.A. 2004. Development of a national wildland fire inventory and fire disaster management action plan for Nigeria. January 2004. [Web:] http://www.fire.uni-freiburg.de/GlobalNetworks/ Africa/Bahagoun-Rep-GFMC-Edited.pdf [Date of access: 25 Feb. 2010].

ADEDOYIN, B.A. \& OLANREWAJU, A.V. 2006. Fire Situation in Nigeria. International Forest Fire News, 32:89-93, Jan.-Jun. [Web:] http://www.fire.uni-freiburg.de/iffn/iffn_34/12-IFFN-34-Nigeria. pdf [Date of access: 25 Feb. 2010]. 
AFRICAN UNION (AU). 2009. Regional achievements and challenges in implementing the Hyogo Framework for Action: Africa's perspective by dr. Abebe Haile Gabriel, acting director of the Department of Rural Economy and Agriculture, African Union Commission. [Web:] http://www.preventionweb. net/files/10866_StatementbyAUCItem3RegionalProgress.pdf [Date of access: 25 Feb. 2010].

AGBO, C.A. 2007. Strengthening the legal frameworks for international response. Paper presented at the International Conference of the Red Cross and Red Crescent in Geneva, Switzerland from 26-30 November 2007. [Web:] http://www.ifrc.org/Docs/pubs/idrl/guidelines/cc-speech-dragbo.pdf [Date of access 25 Feb. 2010].

ALCANTARA-AYALA, I. 2002. Geomorphology, natural hazards, vulnerability and prevention of natural disasters in developing countries. Geomorphology, 47(2-4):107-124, 1 Oct.

ANDERSON, M.B. 1985. A reconceptualisation of the linkages between disasters and development. Disasters, 9 (Supplement):46-51.

ANDERSON, M. 1997. Participatory Development. (In Jenson, E. Development Management Ethics. New York, NY: UNDP. p. 35-41.)

BAWA, P. \& MEIERHANS, I. 2006. First on the front line. [Web:] http://www.redcross.int/EN/mag/ magazine2006_3/24-25.html [Date of access: 25 Feb. 2010].

BEER, T. 2007. The natural hazards theme of the International Year of Planet Earth. Natural Hazards, 42(3):469-480, Sept.

BENSON, C., TWIGG, J. \& MYERS, M. 2001. NGO initiatives in risk reduction: an overview. Disasters, 25(3):199-215, Sept.

BHATT, M.R. 2007. The Hyogo Framework for Action: reclaiming ownership? Humanitarian Exchange Magazine, 38. [Web:] http://www.odihpn.org/report.asp?id=2886 [Date of access 25 Feb. 2010].

CHAGUTAH, T. 2009. Towards improved public awareness for climate related disaster risk reduction in South Africa: A participatory development communication perspective. Jàmbá: Journal of Disaster Risk Studies, 2(2):113-126, Nov.

CUARESMA, C. \& OBERSTEINER, H. 2008. Natural disasters as creative destruction? Evidence from developing countries. Economic Inquiry, 46(2):214-226, Apr.

DEKENS, J. 2007. Local Knowledge for Disaster Preparedness: A Literature Review. Kathmandu, Nepal: International Centre for Integrated Mountain Development (ICIMOD).

DE URIOSTE, A. 2006. When will help be on the way? The status of International Disaster Response Law. Tulane Journal of International and Comparative Law, 15(1):181-206, Winter.

EGBERONGBE, F.O.A., NWILO, P.C. \& BADEJO, O.T. 2006. Oil spill disaster monitoring along Nigerian Coastline. Paper presented at Promoting Land Administration and Good Governance 5th FIG Regional Conference held in Accra, Ghana, March 8-11, 2006. [Web:] http://www.fig.net/pub/accra/ papers/ts16/ts16_06_egberongbe_etal.pdf [Date of access: 25 Feb. 2010].

EHIAWAGUAN, I.P. 2007. Mass casualty incidents and disasters in Nigeria: The need for better management strategies. Nigerian Postgraduate Medical Journal, 14(4):341-346, Dec.

GAILLARD, J.C. \& CADAG, J.R.D. 2009. From marginality to further marginalisation: experiences from the victims of the July 2000 Payatas trashslide in the Philippines. Jàmbá: Journal of Disaster Risk Studies, 2(3):197-215, Dec.

GARBA, E.S., ASUKU, M.E., OGIRIMA, M.O., UKWENYA, Y., ADAMU, A.D. \& UDEZUE, N.O. 2000. Civilian conflicts in Nigeria: the experience of surgeons in Kaduna. The Nigerian Journal of Surgical Research, 2(3-4):144-147. 
GFDRR (Global Facility for Disaster Reduction and Recovery). 2009. Integrating disaster risk reduction into the fight against poverty. Washington: GFDRR. 71p.

GIULIANI, A., WENGER, R. \& VON DACH, S.W. 2009. Disasters risks reduction: A gender and livelihood perspective. InfoResources No 2/09. August 2009. [Web:] http://www.inforesources.ch/pdf/ focus09_2_e.pdf [Date of access: 25 Feb. 2010].

GOYET, C. \& GRIEKSPOOR, A. 2007. Natural disasters, the best friend of poverty. Georgetown Journal on Poverty Law \& Policy, 14:61-94, Winter.

HARRIS, N. 1983. Economic growth and spatial change. Development Planning Unit. Occasional Papers No. 1. University College London.

HULTMAN, N.E. 2006. Worth more than good advice: Lessons of Hurricane Katrina for development in a changing climate. The Georgetown Public Policy Review, 11:47-53.

HYOGO FRAMEWORK FOR ACTION PROGRESS REPORTS. 2010. [Web:] http://www.preventionweb.net/english/hyogo/progress/?pid:181\&pil:1 [Date of access: 25 Feb. 2010].

ICSU (International Council for Science). 2008. A science plan for integrated research on disaster risk: Addressing the challenge of natural and human-induced environmental hazards. Paris, France: ICSU. $66 \mathrm{p}$.

IDMC (Internal Displacement Monitoring Centre). 2009. Nigeria: No end to internal displacement - a profile of the internal displacement situation. [Web:] http://www.unhcr.org/refworld/ docid/4b0658832.html [Date of access: 25 Feb. 2010].

IFRC (International Federation of Red Cross and Red Crescent Societies). 2008. Nigeria: Floods. 19 May 2008. [Web:] http://www.ifrc.org/docs/appeals/07/MDRNG004fr_3.pdf [Date of access: 25 Feb. 2010].

INGRAM, J.C., FRANCO, G., RUMBAITIS-DEL RIO, C. \& KHAZAI, B. 2006. Post-disaster recovery dilemmas: challenges in balancing short-term and long-term needs for vulnerability reduction. Environmental Science \& Policy, 9(7-8):607-613.

KENT, E.F. 2006. Where's the cavalry? Federal response to 21st century disasters. Suffolk University Law Review, 40(1):181-213.

KONOORAYAR, K.V. 2006. Disasters: Global response to the challenges. AALCO Quarterly Bulletin, 2(4):359-384, Dec.

MOMOH, J.A. \& AKINYEDE, J.O. 2008. African regional challenges and position in space-based disaster management and reduction. African Skies, 12:57-63, Oct.

MUANYA, C. 2010. Nigeria hedges on the quake zone. The Guardian: 27 Jan. [Web:] http://www. ngrguardiannews.com/focus_record/article01/indexn2_html?pdate=270110\&ptitle=Nigeriahedgesont hequakezone [Date of access: 25 Feb. 2010].

MUKHTAR, A.B. 2009. Nigeria: Nema plans disaster management framework. Daily Trust. 28 Dec. [Web:] http://allafrica.com/stories/200912290368.html [Date of access: 25 Feb. 2010].

OMONISINI, E.O., ELUDOYIN, A.O. \& SALAMI, A.T. 2010. Towards efficient disaster management in oil pipeline corridors: Example from Nigeria. [Web:] http://www.gisdevelopment.net/application/environment/conservation/DMOPC.htm [Date of access: 25 Feb. 2010].

PELLING, M. \& WISNER, B. 2008. Disaster risk reduction: Cases from urban Africa. London: Earthscan. 200 p.

SAECHAO, T.R. 2007. Natural disasters and the responsibility to protect: From chaos to clarity. Brooklyn Journal of International Law, 32(1):663-707. 
SANDMC (South African National Disaster Mangement Centre). 2003. Disaster mangement guidelines for municipalities. Pretoria: Department of Cooporative Governance and Traditional Affairs. 25p.

SANNI, O.A. 2005. Adulterated kerosene burn disaster: The Nigeria experience. Annals of Burns and Fire Disasters, 18(1):40-44, Mar.

SKELDON, R. 1990. Population Mobility in Developing Countries. London: Belhaven Press.

SRINIVAS, H. \& NAKAGAWA, Y. 2008. Environmental implications for disaster preparedness: Lessons learnt from the Indian Ocean Tsunami. Journal of Environmental Management, 89(1):4-13, Oct.

THE GAMBIA. 2008. National disaster management programme: Strategic plan of action 2008-2011. April 2008. [Web:] http://www.gm.undp.org/Reports/diaster\%2520management\%2520strategic\%25 20action\%2520plan.doc [Date of access: 19 May 2010].

UNDAC (United Nations Disaster Assessment and Coordination Team). 2002. UNDAC Mission to Lagos, Nigeria, 31 January - 7 February 2002: Munitions depot explosion Environmental and humanitarian assessment report. [Web:] http://www.reliefweb.int/ochaunep/edr/NigeriaUNDACreport.pdf [Date of access: 25 Feb. 2010].

VAN NIEKERK, D. 2006. Disaster risk management in South Africa: the function and the activity towards an integrated approach. Politeia, 25(2):96-116.

VAN RIET, G. 2008. Disaster Risk Assessment in South Africa: Some Current Challenges. Paper presented at South African Sociological Association Conference: Society, Power and the Environment: Challenges for the 21st Century, 7-10 July 2008. [Web:] http://acds.co.za/uploads/Conf_Papers/ VanRietG_DisasterriskassessmentinSouthAfrica-somecurrentchallenges.pdf [Date of access: 25 Feb. 2010].

WALKER, P. 2005. The Kobe conference: A review. Humanitarian Exchange Magazine, 29. [Web:] http://www.odihpn.org/report.asp?id=2657 [Date of access: 25 Feb. 2010].

ZOGNING, A., NGOUANET, C. \& TIAFACK, O. 2007. The catastrophic geomorphological processes in humid tropical Africa: A case study of the recent landslide disasters in Cameroon. Sedimentary Geology, 199(1-2):13-27, Jul.

I. See Disaster News. http://www.infopig.com/keywords/Disaster.html (accessed 25 Feb. 2010).

II. International Strategy for Disaster Reduction (ISDR). Hyogo Framework for Action 2005-2015: Building the Resilience of Nations and Communities to Disasters, World Conference on Disaster Reduction (18-22 January 2005). http://www.unisdr.org/wcdr/intergover/official-doc/L-docs/Hyogo-framework-for-action-english.pdf (accessed 25 Feb. 2010).

III. UN General Assembly, 85th Session, 22 December 1989, UN Doc A/RES/44/236.

IV. Id., preambular paragraph 8. See also UN General Assembly Resolution 2816 established UNDRO. UN General Assembly Resolution 2816 (XXVI), 14 December 1989, UN Doc A/RES/2816(XXVI).

V. There have also been such other initiatives as the Committee on Earth Observation Satellites (1984); the Yokohama Strategy for a Safer World: Guidelines for Natural Disaster Prevention, Preparedness and Mitigation and its Plan of Action (1994); International Charter on Space and Major Disaster (1999); the Ice Chart Working Group (1999); the Integrated Global Observing Strategy-Partnership (1999); the Disaster Monitoring Constellation International (2002); the Global Earth Observation System of Systems (2005); and the United Nations Space-based Information for Disaster Management and Emergency Response (2006). 


\section{The Hyogo Framework for Action and its implications for disaster management and reduction in Africa}

VI. Yokohama Strategy and Plan of Action for a Safer World, Guidelines for Natural Disaster Prevention, Preparedness and Mitigation, World Conference on Natural Disaster Reduction Yokohama, Japan, 23-27 May 1994. http://www.unisdr.org/eng/about_isdr/bd-yokohama-strat-eng.htm (accessed 25 Feb. 2010).

VII. HFA, paragraph 27.

VIII. See Countries with National Platforms in DRR. http://www.preventionweb.net/english/countries/africa/ (accessed 25 Feb. 2010).

IX. These were: Algeria; Angola; Burkina Faso; Burundi; Cote d'Ivoire; Egypt; Ghana; Kenya; Madagascar; Mauritius; Mozambique; Senegal; Seychelles; Sierra Leone; Swaziland; Tanzania; Togo; and Zambia. See Countries with National Platforms in DRR. http://www.preventionweb.net/english/hyogo/ progress/?pid:181\&pil:1 (accessed 25 Feb. 2010).

X. See generally Nigeria, Disasters Timeline. http://www.mapreport.com/subtopics/d/countries/nigeria.html (accessed 25 Feb. 2010); A Chronology of Disasters in Nigeria. http://nm.onlinenigeria.com/ templates/?a=5701\&z=17 (accessed 25 Feb. 2010); Jide Ojo. Nigeria Fire Service and Disaster Management Challenge. 19 November 2009. http://jideojong.blogspot.com/2009/11/nigeria-fire-service-and-disaster.html (accessed 25 Feb. 2010)

XI. Act 12, Laws of the Federation of Nigeria, 1990, as amended by Act 50 of 1999. Note that NEMA had been preceded by the defunct National Emergency Relief Agency (NERA), established under NERA Decree 48 of 1976, and charged with the task of collecting and distributing relief materials to disaster victims.

XII. Nigeria: Disaster Management, What Can NEMA Offer?. This Day. 2 Jan 2009, http://www.preventionweb. net/english/professional/news/v.php?id=7921 (accessed 25 Feb. 2010).

XIII. See also Africa Fire Statistics of the Global Vegetation Fire Inventory. October 2002, http://www.fire.unifreiburg.de/inventory/gvfi/afri_stat.htm\#top (accessed 25 Feb. 2010). 